УДК 82I.I6I.I

ББК 83.3 (2Poc=Pyc)
ОТЧЕТ О ВАРШАВСКОЙ КОНФЕРЕНЦИИ, ПОСВЯЩЕННОЙ Д.С. МЕРЕЖКОВСКОМУ (В СВЯЗИ С ЮБИЛЕЙНЫМИ ДАТАМИ)

\author{
(C) 2017 г. Л.А. Колобаева \\ Московский государственный университет \\ им. М.В. Ломоносова, Москва, Россия \\ Дата поступления статьи: 27 декабря 2017 г. \\ Дата публикации: 25 июня 2017 г.
}

DOI: I0.22455/2500-4247-20I7-2-2-324-333

Информация об авторе: Лидия Андреевна Колобаева - доктор филологических наук, профессор, Московский государственный университет им. М.В. Ломоносова, Воробьевы горы, МГУ, г корпус гуманитарных факультетов, Филологический факультет, к. 967, г19899 Москва, Россия.

E-mail: 1.a.kolobaeva@gmail.com 


\section{ANNIVERSARY CONFERENCE ON DMITRY MEREZHKOVSKY IN WARSAW}

This is an open access article distributed under the Creative Commons Attribution 4.0 International (CC BY 4.O)
(C) 20I7. L.A. Kolobaeva

M.V. Lomonosov Moscow State University, Moscow, Russia

Received: December 27, 2017

Date of publication: June 25, 2017

Information about the author: Lidiya A. Kolobaeva, DSc in Philology, Professor, M.V. Lomonosov Moscow State University, Vorobyovy Gory, ${ }^{\text {st }}$ Humanities, Faculty of Philology, Room 967, i19899 Moscow, Russia.

E-mail: l.a.kolobaeva@gmail.com 
2I-23 апреля 20I6 г. в Варшавском университете состоялась международная научная конференция «Д.С. Мережковский: литератор, религиозный философ, социальный экспериментатор», посвященная I50-летию со дня рождения, 75-летию со дня смерти, 95-летию пребывания в Варшаве крупнейшего русского литературного деятеля XX в. Конференция была организована кафедрой восточноевропейской культурологии Института специальной и межкультурной коммуникации Варшавского университета совместно с Институтом литературы Болгарской Академии наук. В работе конференции приняли участие исследователи из Польши, России, Болгарии, Украины, Германии, Италии, Грузии, Беларуси, Латвии... По итогам конференции издан тематический номер журнала “Toronto Slavic Quarterly” [2].

Главное, и очень живое, устремление Варшавской конференции, как это прочитывается в докладах, - представить Д.С. Мережковского в многообразии и всеохватности его творческих проявлений. В той многосторонности и разветвленности путей, способов и форм «самосотворения» личности и литературы, которых так не хватает нам сегодня. А разносторонность его деятельности, в самом деле, поразительна. Это его «социальные и религиозно-философские практики» - прогнозы и сопротивление воинственному духу «желтолицего» позитивизма, поиски возможностей религиозного сообщества со старообрядцами, с народной средой; раздумье о драме противоречий и насилии в истории религиозной реформации (эссе о Кальвине); обоснование духовной программы в ее идеальном выражении («портрет» св. Франциска Ассизского); выяснение полижанровой структуры его «исторического» романа. Это диалоги писателя с литераторами-со- 
временниками, с настоящим и прошлым, преломления и отзвуки голоса Мережковского в современной ему русской литературе; наконец, отражение его творчества в инонациональных культурах (немецкой, итальянской, болгарской, в «китайском мире» (Китай, Тайвань, Япония)). Сверх того, открывается (почти не упоминаемое прежде) непосредственное участие поэта в коммерции, рекламе и в политике, что неожиданно и актуально, и потому с них, с этих проблем, конференция и начинается.

В первых двух докладах - Алексея Холикова («"Автобиографическая заметка” и стратегия самосотворения во втором прижизненном “Полном собрании сочинений” Д.С. Мережковского») и Вадима Полонского («Стратегия Д.С. Мережковского по завоеванию европейского литературного рынка на рубеже XIX-XX вв.: ранние методы самопрезентации и западные “агенты влияния” ) - видна существенная их общность в подходе к материалу. Вводя в научный обиход новый или малоизвестный фактический материал (извлеченная из Архива «Автобиографическая заметка» в сопоставлении с ее авторедакторскими правками в печатных вариантах у А. Холикова, материал эпистолярный и газетный, из французских газет, - в докладе В. Полонского), докладчики мастерски соединяют факты с перспективой широкой, обобщающей мысли. Тем самым обозначается выстраиваемая писателем «стратегия» его творчества и поведения, вырисовывается программа «самостроения». Эту общую стратегию Д. Мережковского, от «Автобиографической заметки» (I9I3) к первому «Полному собранию сочинений» I9I4 г., А. Холиков выводит и формулирует последовательно, лаконично и в заключение статьи - по пунктам, как пристало науке, желающей быть точной: Мережковский религиозен с детства; для него принципиально важно общение с лучшими современными писателями; он - не декадент, а символист; он - оригинальный мыслитель; революционно настроен по отношению к церкви и старой России; писатель хорошо работает с фактами и др. Вывод А. Холикова - Мережковский пересмотрел свое «отношение к Толстому» [2, с. 22] - подготовлен сопоставлением оценок из книги «Лев Толстой и Достоевский» с «Автобиографической заметкой», где звучит признание писателя: «несмотря на глубочайшие умственные расхождения», Толстой ему «все-таки сердечно, религиозно ближе, роднее Достоевского» [2, с. I7]. Этот авторский корректив существенен в сознании Мережковского, в общей его творческой динамике. 
Не утрачивают своей остроты вопросы о политике, об отношении к ней Мережковского. Об этом вызывающий несомненный интерес доклад Людмилы Луцевич «Лицом к лицу: две встречи». Это размышление о встречах писателя с Пилсудским и Муссолини на материале двух его очерков («Иосиф Пилсудский», І920, и «Встреча с Муссолини», І937). Мережковскому, подчеркивает докладчик, всегда была свойственна многофункциональность творчества и выходы за пределы чистой художественности. В роли политика он выступал не однажды, в 1905 г. и особенно после I9I7 г., общался с эсерами и неонародниками, контактировал с Керенским, Савинковым и другими. Чем мотивировалась его встреча с двумя диктаторами - Пилсудским и Муссолини? Современники, как замечает докладчик, отвечали на этот вопрос просто - это стремление Мережковского к свержению большевистской власти в России и его меркантильные интересы. Л. Луцевич стремится расширить и уточнить мотивацию, как и картину в целом. Проявленный писателем в очерках «сервилизм» она готова связать с традицией давнего, привычного отношения поэтов к царствующей власти, начиная с Ломоносова и Державина, однако и отделяет от нее Мережковского, напоминая, что теперь перед ним «чужие” [здесь и далее курсив и полужирный курсив в цитатах мой. - Л.К.] властители» [2, с. 54]. Писатель мифологизирует героев своих очерков, при встречах с Пилсудским и Муссолини делает «попытку личного воздействия» на них. И главной причиной обращения к ним (как это выясняется из контекста статьи в ее целом) является сокрушительное нарастание в сознании Мережковского ощущения близящейся катастрофы мира, когда решается для него вопрос «быть или не быть?» [2, с. 56]. Подобный вывод, с усилением его смысла, выносится и в другой статье, стоящей рядом и перекликающейся с Л. Луцевич. Это яркая работа Нины Барковской «ААти-Данте” как автопсихологическая проекция Дмитрия Мережковского». Здесь вырисовывается необычный образ Данте - Анти-Данте, не похожий на творца «Божественной комедии», поэт в состоянии крайней тревоги, предчувствия некоего устрашающего мирового «взрыва» [2, с. 64]. Такой образ Данте был выражением субъективной психологии самого Мережковского, ее двойственности. Выражением того напряженного состояния русского писателя в зо-е гг., когда в большевизме ему виделось нашествие мирового «метафизического зла» [2, с. 5I, 64], угрожающего гибелью всей накопленной человечеством культуры. 
В группе докладов по социальным и религиозно-философским «практикам», как необходимые друг другу полюса, соотносятся между собой два ключевых доклада - Елены Андрущенко и Александра Медведева. В первом исследуются прогнозы Мережковского на будущее - прогнозы критические, связанные с развитием потенций крайнего зла, «Грядущего Хама», в массовом сознании, во втором - истоки явленной в прошлом и чаемой в настоящем и будущем истинной христианской веры, веры Франциска Ассизского. Елена Андрущенко отказывается толковать «Грядущего Хама» так, как это делалось прежде ею самой и другими исследователями, - толковать его «просто и прямо». Теперь она резко усложняет пути интерпретации. Расширяет контекст и, связывая между собой контекстными перекличками и смысловыми созвучиями целый круг работ Мережковского (близких по времени к «Грядущему Хаму» - о Белинском, о Гоголе, «желтолицых позитивистах»), отыскивает в них новые смысловые оттенки в дополнение к ключевым образам-понятиям статьи - хам, раб, мещзанин, черт - и к отношениям: хам и культура, раб и государство и др. В итоге исследовательница приходит к заключению, что в символике Грядущего Хама - помимо предупреждений писателя об опасностях массового сознания, о возможных кризисах политических, государственных и социальных - сильнейшей оказывается тревога Мережковского о личности, которая готова стать, «как все» [2, с. 85]. И это, разумеется, правильно. Только стоит, пожалуй, добавить, что, по убеждению Мережковского, «все дела, чувства и мысли» в современной европейской культуре кончаются одним - «острием личности» [3, с. 218].

В своем докладе «Св. Франциск Ассизский в творчестве Д. Мережковского и русская “францискиана” (Достоевский, Розанов, Дурылин)» Александр Медведев обосновывает значимость сделанного Мережковским открытия в русской литературе рубежа XIX-XX вв. - образа Франциска Ассизского (поэма «Франциск Ассизский. Легенда» в сборнике «Приложений» к журналу «Нива», г89г г., №3 и в сборнике «Символы», г892 г.). Это образ «итальянского святого в России», ставшего вскоре «литературным русским святым», святым интеллигенции, по словам В. Розанова [2, с. 88]. Исследователь устанавливает, что Мережковский развертывает в поэме отсутствующую в известной францисканской агиографии и очень важную образную антитезу «сурового аскета» Сильвестра и Франциска Ассизского [2, 
c. 94] - просветленного, исполненного неистребимой радости жизни, любви к живой природе и человеческому миру. Первоистоком открытия Мережковского был Достоевский, и с него-то, собственно, статья А. Медведева и начинается. В главе «Великий Инквизитор» («Братья Карамазовы») содержится прямое соотнесение старца Зосимы с Франциском Ассизским (на что указала еще В.Е. Ветловская и на нее ссылается А. Медведев [2, с. 86]). Кульминационную значимость этой главы романа с ее первоначальным названием - «Pater Serafiphicus» (имя Франциска) - Достоевский подчеркивал в письме к редактору Н.А. Любимову (от II июня I879 г.), выдержки из которого рассматриваются в статье. В связи с этим здесь приводится знаменательное признание писателя в «общехристианской» цели шестой книги, а также его мысль о том, что «чистый, идеальный христианин - дело не отвлеченное, а образно реальное, возможное» [г, с. 68-69], «соединяющее православное и католическое благочестие» [2, с. 87]. Образное воплощение подобных идей, в чем нас убеждает предложенный А. Медведевым конкретный и интертекстуальный анализ художественного текста Достоевского (образ кельи Зосимы с иконами православными и католическими, его свобода в отношении поста, диалоги с проповедником жесткого и неукоснительного аскетизма о. Ферапонтом и т. д.), и явило собой первоисток «францискианы» в русской литературе, который будет распространяться и дальше.

Как устанавливает докладчик, францисканские мотивы проявились в творчестве Алексея Толстого (поэма «Иоанн Дамаскин»), получили свое развитие в поэме Мережковского о Франциске Ассизском и в его францисканском прочтении пушкинских «Цыган», прозвучали в критике аскетизма у В. Розанова, Н. Бердяева и С.Н. Дурылина. А. Медведеву удается выявить существование в русской литературе определенной, весьма весомой, традиции францискианы, в которую и вписывается творчество Д. Мережковского.

Среди теоретических вопросов наиболее существенным представляется вопрос о специфике жанра исторического романа, на котором концентрируется внимание в работе Дьердь Золтана Йожи «Миф и инициация. К проблеме “полижанровости” романа Мережковского “Рождение богов. Тутанкамон на Крите”. Исследователь рассматривает проблему жанра романа Мережковского на широком историко-литературном и 
культурном фоне, в сопоставлении специфики романного жанра у Толстого, Достоевского, Андрея Белого - в свете суждений о них М. Бахтина, самого Мережковского и современных исследователей. Он прослеживает трансформацию биографического или «отказ от биографии» в романе, ориентацию на жанр жития (у Достоевского), полифункциональность мифа и соотнесенность каждого момента человеческого бытия с космическим началом (у А. Белого). Ученый обнаруживает подобные жанровые качества в романе «Рождение богов. Тутанкамон на Крите» и обосновывает определение его жанровой специфики как «романа инициации», посвящения. При этом не вызывает согласия предложение Дьердь Золтана Йожи отбросить обозначение жанра романов Мережковского как «исторического романа» [2, с. I25, І29-І 30]. Верно, что к этому общему определению надо искать и находить обозначение его специфических, в каждом отдельном случаев дополнительных признаков и красок. Но отказываться от знакового имени «исторического романа», рожденного у Мережковского главным устремлением всего его творчества - принципом «религиозно-исторического познания» мира и человека, думаю, нет достаточного резона.

Выразительные штрихи к «портрету» Мережковского и его сознания запечатлевают доклады под рубрикой: «Диалоги, контраверсии, воспоминания» - Марии Цимборска-Лебода о диалоге Вяч. Иванова с Мережковским, Марии Кшондзер о П. Чаадаеве в оценке Мережковского, Taмар Гоголадзе и Нино Миндиашвили о Мережковском в восприятии Григола Робакидзе, Александра Федуты - о Павле I в пьесах Мережковского и Всеволода Иванова, Ивоны Крыцка-Михновска - о Мережковском во всех многочисленных дневниках и воспоминаниях жены. Здесь исследуются некие художественные отклики, реакции писателей-современников, их «ответ» на произведения Мережковского. Выделяется при этом доклад Екатерины Кузнецовой «Отражение философско-религиозных идей Д. Мережковского в симфонии “Кубок метелей” и романе “Серебряный голубь” Андрея Белого». В «Кубке метелей», полагает докладчик, любовь осмысливается через чувство Бога, в духе идей Мережковского, с преломлением его «верхней бездны», бездны духа. Роман «Серебряный голубь» оценивается более критически. В нем одерживает верх гротескно-ироническая и сатирическая трактовка событий, с торжеством «нижней бездны» в них. В герое романа 
Кудеярове, одним из прототипов которого был сам Мережковский, Белый усматривает «одержимость сектанта» [2, с. I88].

Особенно актуальная проблематика, еще не так давно нам почти недоступная, содержится в разделе докладов об «инокультурной рецепции» Мережковского. Здесь продемонстрирован процесс активной рецепции его творчества во многих европейских странах - в Германии, Италии, Болгарии, Латвии, а также в Китае, Японии и других странах процесс, начавшийся в конце XIX в., продолжающийся и сегодня. Факты многочисленных изданий произведений Мережковского свидетельствуют об авторитетности писателя в этих странах. При этом в его творчестве выделяются в переводах прежде всего его исторические романы, трилогия «Христос и Антихрист», чаще всего первый роман об античной эпохе и второй, о Возрождении, привлекают внимание литературно-критические исследования писателя («Вечные спутники», «Л. Толстой и Достоевский»), религиозно-философские труды («Иисус Неизвестный»), а также многие публицистические статьи писателя. Анализ рецепции Мережковского в Болгарии (доклад Йордана Люцканова) свидетельствует и о таком печальном факте в истории литературных отношений России (тогда Советского Союза) и славянских стран, как полувековое замалчивание писателя (с 1930-х гг. до І990-х), копирующее литературную политику России того времени.

Рельефную картину восприятия Мережковского в Германии развертывает в своем докладе Ольга Богданова - «Дмитрий Мережковский и мюнхенское издательство “Пипер” в первой трети XIX в. (межкультурная трансляция концепта “земля”)». Интерес в Германии к Достоевскому, немецкое издание «Льва Толстого и Достоевского» в І903 г., внимание к событиям русской революции г905 г. и к формированию концепта «земля» как истока концепта «плоти» и нового религиозного сознания у Мережковского находит отклик в немецкой философской и публицистической критике и оказывает влияние на нее. Красноречивы здесь приводимые О. Богдановой свидетельства - прозвучавшие в печати параллели Мережковского с Ницше, «русский след» в «Закате Европы» Шпенглера, противоречивые толкования «земли» среди немецкой интеллигенции, у сторонников «консервативной революции» и, наконец, восторженный отзыв Т. Манна о Мережковском как гениальном критике. Впечатляюща также хроника мно- 
гочисленных мюнхенских изданий и переизданий книг, сборников эссе и дневника Мережковского.

Говоря о Варшавской конференции, невозможно забыть еще об одном ее участнике - это смех, прозвучавший в докладе Вячеслава Крылова о Мережковском в пародиях начала XX в., и веселый, остроумный смех стихотворных шуток Александра Федуты обо всем прослушанном.

Завершающей точкой Варшавской конференции стал молчаливый свидетель жизни Д. Мережковского - его фотографические и живописные портреты (в профессионально точном описании Гражины Бобилевич «Иконография Дмитрия Мережковского»). И мы можем судить, как выглядел писатель, как одевался, как «держал себя», каким был и казался, каким виделся современникам. Все это весьма примечательно.

Нельзя не признать в заключение, что Варшавская конференция стала живым и остросовременным форумом, который широко развернул и углубил наши научные представления о творческом наследии Д.С. Мережковского - необычайного явления русской литературы Серебряного века.

\section{Список литературы}

I Достоевский Ф.М. Полн. собр. соч.: в 30 т. Л.: Наука, І988. Т. зо. Кн. І. 456 с.

2 Д.С. Мережковский: литератор, религиозный философ, социальный экспериментатор / ред. Н. Барковская, Л. Луцевич, Й. Люцканов, А. Медведев // Toronto Slavic Quarterly. Academic Electronic Journal in Slavic Studies. 20I6. №57. 424 c. Эл. версия: http://sites.utoronto.ca/tsq/57/index57.shtml

3 Мережковский Д. Розанов // Мережковский Д. Больная Россия / сост. А.Н. Николюкин. М.: Республика, 2011. С. 215-222.

\section{References}

I Dostoevskii F.M. Polnoe sobranie sochinenii: $v$ zo $t$. [Complete collection of works: in 30 vol.]. Leningrad, Nauka Publ., I988. Vol. 30. Book I. 456 p. (In Russ.)

2 D.S. Merezhkovskii: literator, religioznyi filosof, sotsial'nyi eksperimentator [D.S. Merezhkovsky: a writer, a philosopher of religion and a social experimenter], ed. N. Barkovskaya, L. Lutsevich, J. Lyutskanov, A. Medvedev. Toronto Slavic Quarterly. Academic Electronic Journal in Slavic Studies, 2016, no 57. 424 p. Electronic version: http://sites.utoronto.ca/tsq/57/index57.shtml (In Russ.)

3 Merezhkovskii D. Rozanov [Rozanov]. Merezhkovskii D. Bol'naia Rossiia [Patient Russia], ed. A.N. Nikoliukin. Moscow, Respublika Publ., 20II, pp. 2I5-222. (In Russ.) 